Volume 7 No. 2, Juli-Desember 2020

P-ISSN: 2406-808X // E-ISSN: 2550-0686

https://journal.iainlangsa.ac.id/index.php/ikhtibar

https://doi.org/10.32505/ikhtibar.v7i2.618

\title{
PENGGUNAAN MEDIA PEMBELAJARAN UNTUK MENINGKATKAN PRESTASI BELAJAR SISWA PADA PELAJARAN PKN \\ DI SMA SWASTA DARUSSA'ADAH \\ KEC. PANGKALAN SUSU
}

\author{
Ahmad Zaki, Diyan Yusri \\ STAI JM Tanjung Pura \\ riyusyandi@gmail.com
}

\begin{abstract}
This study aims to improve student learning outcomes in PKN learning through learning that is equipped with learning media. The subjects of this study were Grade XI Students at Darussaadah Private Kec. Kec. Pangkalan Susu Kab. Langkat, totaling 40 people consisting of 20 male students and 20 female students. The research method applied is the classroom action research method through two learning cycles. Each cycle carried out planning, implementation, observation and reflection. based on the results of data analysis it is known that through PKN learning in class XI Darussaadah Kec. Milk Base for 2018/2019 Academic Year, student activity has increased from the first cycle to obtain a classical score of 767 with a percentage of the acquisition score to a total score of $59.92 \%$ and this is included in both categories. In the second cycle the classical activity of students gained a score of 1089 with the percentage of the acquisition score to a total score of $85.08 \%$ and this is included in the very good category. So the increase in student learning activities cycle from cycle I to cycle II by $25.16 \%$ while for student learning outcomes after learning is applied by using complete learning media on PKN learning in class XI Darussaadah Private High School Kec. Pangkalan Susu has also increased. In cycle I, the acquisition of classical average value was 73.23. The average value is below the minimum criteria for completeness $(\mathrm{KKM}=75)$ and $80 \%$ for completeness (completeness). The number of students who completed as many as 27 people or $67.50 \%$ while in the second cycle obtained a classical average value of 79.63 with the number of students who completed 33 students or $82.5 \%$ this means the average value obtained has reached KKM which is determined so that the student learning completeness indicator is achieved. Likewise, the number of students who have completed has reached an indicator of success, where the standard is set at $80 \%$ while the acquisition reaches $82.5 \%$.
\end{abstract}

Keywords: learning media, learning achievement, $P K N$

\begin{abstract}
ABSTRAK
Penelitian ini bertujuan untuk meningkatkan hasil belajar siswa dalam pembelajaran PKN melalui Pembelajaran yang dilengkapi dengan media pembelajara. Subjek penelitian ini adalah Siswa Kelas XI SMA Swasta Darussaadah Kec. Pangkalan Susu Kab. Langkat, berjumlah 40 orang terdiri dari 20 orang siswa laki-laki dan 20 orang siswa perempuan. Metode
\end{abstract}


penelitian yang diterapkan adalah metode penelitian tindakan kelas melalui dua siklus pembelajaran. Setiap siklus dilakukan kegiatan perencanaan, pelaksanaan, pengamatan dan refleksi . berdasarkan hasil analisis data diketahui bahwa melalui pembelajaran PKN di kelas XI SMA Swasta Darussaadah Kec. Pangkalan Susu Tahun Pelajaran 2018 / 2019, aktivitas siswa mengalami peningkatan dari siklus pertama memperoleh skor klasikal 767 dengan persentase skor perolehan terhadap skor total sebesar 59,92\% dan ini termasuk kategori baik. Pada siklus kedua aktivitas siswa secara klasikal memperoleh skor 1089 degan persentase skor perolehan terhadap skor total sebesar 85,08\% dan ini termasuk dalam kategori sangat baik. Jadi peningkatan aktivitas belajar siswa siklus dari siklus I ke siklus II sebesar $25,16 \%$ sedangkan untuk hasil belajar siswa setelah diterapkan pembelajaran dengan menggunakan media pembelajaran lengkap pada pemebelajaran PKN di kelas XI SMA Swasta Darussaadah Kec. Pangkalan Susu juga mengalami peningkatan. Pada siklus I perolehan nilai rata-rata klasikal 73,23. Nilai ratarata ini masuk dibawah nilai kriteria ketuntasan minimal yang ditetapkan $(K K M=75)$ dan indikator keberhasilan (ketuntasan) 80\%. Jumlah siswa yang tuntas sebanyak 27 orang atau 67,50 \% sedangkan pada siklus II di peroleh nilai rata-rata klasikal 79,63 dengan jumlah siswa yang tuntas 33 orang siswa atau $82,5 \%$ ini berarti nilai rata-rata yang diperoleh sudah mencapai KKM yang ditetapkan sehingga indikarot ketuntasan belajar siswa tercapai. Demikian juga dengan jumlah siswa yang tuntas sudah mencapai indikator keberhasilan, dimana standar yang ditetapkan $80 \%$ sedangkan perolehan mencapai $82,5 \%$.

Kata kunci : media pembelajaran, prestasi belajar, PKN

\section{Pendahuluan}

Mata Pelajaran PKN merupakan mata pelajaran yang memfokuskan pada pembentukan warga negera yang memahami dan mampu melaksanakan hal-hal dan kewajibannya untuk menjadi Warga Negara Indonesia yang cerdas, terampil dan berperilaku sebagai mana yang diamanatkan oleh Pancasila dan UUD 1945. Untuk itu di alam Reformasi, karakter PKN yang demokratis tersebut, menjadi bagian dari tugas Guru PKN untuk mengembangkannya secara profesional melalui memingkatanya hasil belajar siswa. Meningkatnya prestasi belajar siswa adalah melalui memotivasi minat siswa terhadap pelajaran PKN. Dalam hal ini Guru PKN akan berusaha mengikuti dan mengembangkan melalui model dan media pembelajaran.

Mata pelajaran PKN adalah merupakan bagian muatan kurikulum yang harus dituntaskan, khususnya muatan kurikulum jenjang SMA. Dunia pendidikan khususnya jenjang SMA Mempunyai peran penting dalam rangkan menghasilkan SDM yang tidak hanya cerdas, tetapi terampil dan bermoral tinggi yang dikenal dengan pembangunan Manusia Indonesia seutuhnya. Komponen yang terkait dalam dunia pendidikan baik keluarga, masyarkat dan juga pemerintah terus melakukan berbagai upaya untuk membangun manusia pancasila.

Peningkatan mutu pendidikan akan tercapai apabila proses pembelajaran yang diselenggarakan di kelas benar-benar efektif dan berguna untuk mencapai kemampuan pengetahuan, sikap dan keterampilan yang diharapkan. Karena pada dasarnya proses belajar mengajar merupakan inti dari proses pendidikan secara keseluruhan. Tetapi untuk meningkatkan mutu pendidikan tersebut masih terdapat permasalahan atau penghambat dalam proses pembelajran yang dihadapi oleh guru di sekolah sehingga menyebabkan rendahnya hasil belajar siswa. Pendidikan memegang 
peranan penting dalam menghasilkan sumber daya manusia yang berkualitas. Melalui pendidikan maka manusia dituntut untuk belajar. Dalam keseluruhan proses pendidikan sekolah kegiatan proses pembelajaran merupakan tujuan pendidikan tergantung bagaimana proses pembelajaran yang dialami siswa sebagai anak didik untuk meningkatkan semangat belajar siswa.

Meningkatkan kualitas pembelajaran merupakan salah satu hal penting yang harus diperhatikan dalam suatu proses pembelajaran untuk meningkatkan mutu pendidikan. Hal ini merupakan tugas masing-masing sekolah dan yang paling utama adalah bagi guru sebagai tenaga pengajar. Guru harus selalu kreatif dan inovatif dalam melakukan pembelajaran agar siswa lebih mudah memahami materi yang disampaikan dan atusias dalam mengikuti proses belajar mengajar, sehingga pembelajaran yang dilaksanakan berkualitas dan prestasi yang tercapai siswa memuaskan.

Masalah utama dalam pembelajaran pada pendidikan dewasa ini masih didominasi oleh pandangan bahwa pengetahuan merupakan perangkat fakta yang harus dihapal. Kelas masih berfokus pada guru sebagai sumber utama pengetahuan dan ceramah menjadi pilihan utama dalam strategi mangajar. Hal ini tempak dari rerata hasil belajar peserta didik yang disebabkan dominannya proses pembelajaran konvensional. Pada pembelajaran ini suasana kelas cenderung teacher-centerd sehingga siswa menjadi pasih. Meskipun demikian guru lebih suka menerapkan model tersebut, sebab tidak memerlukan alat dan bahan praktek, cukup menjelaskan konsep-konsep yang ada dalam buku ajar dan refrensi lain. Dalam hal ini, siswa tidak diajarkan strategi belajar yang dapat memahami bagaimana belajar, berfikir dan memotivasi diri sendiri (self motivation) pada hal aspek aspek tersebut merupakan kunci keberhasilan dalam suatu pembelajaran. Masalah seperti ini banyak dijumpai dikelas.

Ada beberapa permasalahan yang ditemukan di dalam kelas XI SMA Swasta Darussaadah Kec. Pangkalan Susu pada saat proses belajar mengajar, yaitu:

1. Pada umumnya guru hanya menggunakan metode ceramah sehingga kurang melibatkan siswa.

2. Hasil belajar PKN masih rendah

3. Kurangnya minat belajar siswa

4. Kurangya kemampuan guru dalam memvariasikan dan memilih model pembelajaran yang sesuai dengan materi.

5. Siswa kurang aktif dalam belajar

6. Guru tidak menggunakan media pembelajaran secara maksimal.

7. Nilai PKN siswa yang belum mencapai Kriteria Ketuntasan Minimal (KKM) yang ditetapkan sekolah. Semua permasalahan ini pada akhirnya akan berpengaruh pada prestasi belajar siswa.

Hasil belajar siswa kelas XI SMA Swasta Darussaadah Kec. Pangkalan Susu tidak tuntas secara keseluruhan baik ketuntasan individu maupun ketuntasan klasikal. Perlu dilakukan perubahan dalam proses pembelajaran dengan menerapkan suatu strategi belajar yang dapat membantu siswa untuk memaham materi ajar dan menekankan perenan aktif siswa. Maka penulis merasa perlu untuk melakukan penelitian dikelas XI mata pelajaran PKN di SMA Swasta Darussaadah Kec. Pangkalan Susu. Jika Proses pembelajaran siswa dilaksanakan dengan menggunakan media pembelajaran dan kelengkapan buku siswa maka akan meningkatkan prestasi belajar siswa pada mata pelajaran PKN di kelas XI SMA Swasta Darussaadah Kec. Pangkalan Susu tahun pelajaran 2018-2019. 
Aktivitas belajar adalah aktivitas yang bersifat fisik ataupun mental (Sardiman,2001). ${ }^{1}$ Dalam proses belajar mengajar, guru perlu menimbulkan aktivitas siswa dalam berpikir maupun berbuat. Penerimaan pembelajaran jika dengan aktivitas siswa sendiri, karena itu tidak akan perlu begitu saja. Tetapi dipikirkan, diolah kemudian dikeluarkan lagi dalam bentuk yang berbeda atau siswa akan bertanya, mengajukan pendapat, menimbulkan diskusi dengan guru. Dalam berbuat siswa dapat menjalankan perintah, melaksanakan tugas, membuat grafik, diagram, inti sari dari pelajaran yang disajikan oleh guru.

Bila siswa menjadi partisipasi yang aktif, maka ia memiliki ilmu pengetahuan dengan baik. Dalam belajar seseorang tidak dapat menghindarkan diri dari suatu situasi yang akan menentukan aktivitas yang akan dilakukan dalam rangka belajar. Kata media berasal dari bahasa latin medius yang secara harfiah berarti tengah, perantara atau pengantar. Dalam bahasa arab, media adalah perantara atau pengantar pesan dari pengirim kepada penerima pesan (Arsyad, 2007). ${ }^{2}$ Media berasal dari bahasa latin merupakan bentuk jamak dari Medium yang secara harfiah berarti perantara atau pengantar yaitu perantara atau pengantar sumber dengan penerima pesan. Beberapa ahli memberikan definisi tentang media pembelajaran. Media pembelajaran adalah teknologi pembawa pesan yang dapat dimamfaatkan untuk keperluan pembelajaran. Media pembelajaran adalah sarana fisik untuk menyampaikan isi/ materi pembelajaran seperti : buku, film, video dan sebagainya. Media pembelajaran adalah sarana komunikasi dalam bentuk cetak maupun pandangan yang termasuk teknologi perangkat keras.

Ketiga pendapat diatas disimpulkan bahwa media pembelajaran adalah segala sesuatu yang dapat menyalurkan pesan, dapat merangsang pikiran,perasaan, dan kemauan peserta didik sehingga dapat mendorong terciptanya proses belajar pada diri peserta didik. Selain itu juga mampu menggunakan alat-alat yang tersedia, guru juga dituntut untuk dapat mengembangkan keterampilan membuat media pembelajaran yang akan digunakannya apabila media tersebut belum tersedia. Untuk itu guru harus memiliki pengetahuan dan pemahaman yang cukup tentang media pembelajaran, yang meliputi :

a) Media sebagai alat komunikasi guna lebih mengefektifkan proses belajar mengajar.

b) Fungsi media dalam rangka mencapai tujuan pembelajaran

c) Seluk-beluk proses belajar

d) Hubungan antara metode mengajar dan media pendidikan

e) Nilai atau mamfaat media pendidikan dalam pengajaran

f) Pemilihan dan penggunaan media pendidikan

g) Berbagai jenis alat dan teknik media pendidikan

h) Media pendidikan dalam setiap mata pelajaran

i) Usaha inovasi dalam media pendidikan

Dengan demikian, dapat disimpulkan bahwa media adalah bagian yang tidak terpisahkan dari proses belajar mengajar demi tercapainya tujuan pendidikan pada umumnya dan tujuan pembelajaran disekolah pada khususnya.

Ahmadi menjelaskan Pengertian Prestasi Belajar sebagai berikut: Secara teori bila sesuatu kegiatan dapat memuaskan suatu kebutuhan, maka ada kecenderungan besar untuk mengulanginya. Sumber penguat belajar dapat secara ekstrinsik (nilai,

\footnotetext{
${ }^{1}$ Sardiman, Arif. 2008. Media Pendidikan. Jakarta: Kencana Prenada Media Group.

${ }^{2}$ Azhar, Arsyad. 2009. Media Pembelajaran. Jakarta.; Raja Grafindo Persada, Rineka Cipta.
} 
pengakuan, penghargaan) dan dapat secara ekstrinsik (kegairahan untuk menyelidiki, mengartikan situasi). ${ }^{3}$

Disamping itu siswa memerlukan/ dan harus menerima umpan balik secara langsung derajat sukses pelaksanaan tugas (nilai raport/nilai test) (Psikologi Belajar DRS.H Abu Ahmadi, Drs. Widodo Supriyono 151).

Definisi diatas dapat disimpulkan bahwa pengertian prestasi belajar ialah hasil usaha bekerja atau belajar yang menunjukan ukuran kecakapan yang dicapai dalam bentuk nilai. Sedangkan prestasi belajar hasil usaha belajar yang berupa nilainilai sebagai ukuran kecakapan dari usaha belajar yang telah dicapai seseorang, prestasi belajar ditunjukan dengan jumlah nilai raport atau test nilai sumatif

\section{Landasan Teori}

Definisi Media Pembelajaran Nunu Mahnun (2012) menyebutkan bahwa "media" berasal dari bahasa Latin "medium" yang berarti "perantara" atau "pengantar".Lebih lanjut, media merupakan sarana penyalur pesan atau informasi belajar yang hendak disampaikan oleh sumber pesan kepada sasaran atau penerima pesan tersebut. ${ }^{4}$ Penggunaan media pengajaran dapat membantu pencapaian keberhasilan belajar. Menurut AECT (Association of Education and Communication Technology) yang dikutip oleh Basyaruddin (2002) "media adalah segala bentuk yang dipergunakan untuk proses penyaluran informasi" . Sedangkan menurut Steffi Adam dan Muhammad Taufik Syastra (2015) bahwa media pembelajaran adalah segala sesuatu baik berupa fisik maupun teknis dalam proses pembelajaran yang dapat membantu guru untuk mempermudah dalam menyampaikan materi pelajaran kepada siswa sehingga memudahkan pencapaian tujuan pembelajaran yang telah dirumuskan. ${ }^{6}$ Selanjutnya (Joni Purwono, dkk, 2014) menjelaskan bahwa media pembelajaran memiliki peranan penting dalam menunjang kualitas proses belajar mengajar. ${ }^{7}$ Media juga dapat membuat pembelajaran lebih menarik dan menyenangkan. Salah satu media pembelajaran yang sedang berkembang saat ini adalah media audiovisual. Dari pengertian di atas dapat disimpulkan bahwa media pembelajaran adalah alat bantudalam proses belajar mengajaruntuk merangsang pikiran, perasaan, perhatian dan kemampuan atau ketrampilan pembelajar sehingga dapat mendorong terjadinya proses belajar. Jenis-jenis Media Pembelajaran Perkembangan pendidikan yang sangat pesat, berpengaruh pada perkembangan psikologi belajar serta pada sistem pendidikan yang ada.Keadaan tersebut, mendorong dan berakibat juga pada kemajuan teknologi pembelajaran dan penambahan baru pada media pembelajaran.Seiring dengan kemajuan teknologi, maka perkembangan media pembelajaran begitu cepat, di mana masingmasing media yang ada punya ciri-ciri dan kemampuan sendiri. Dari hal ini, kemudian timbul usaha-usaha penataannya yaitu pengelompokkan atau klasifikasi menurut kesamaan ciri-ciri atau karakteristiknya. Ciri-ciri umum dari media pembelajaran menurut (Oemar Hamalik, 1994), adalah: Pertama, Media pembelajaran identik dengan pengertian peragaan yang berasal dari kata "raga", artinya suatu benda

${ }^{3}$ Ahmadi dkk, Drs. H. Abu. (2004). Psikologi Belajar. Jakarta : PT. Rineka Cipta. Vol. 2.

${ }^{4}$ Mahnun.Nunu.(2012). Media Pembelajaran (Kajian terhadap Langkah-langkah Pemilihan Media dan Implementasinya dalam Pembelajaran). Dalam Jurnal Pemikiran Islam; Vol. 37, No. 1: 27

${ }^{5}$ Asnawir dan M. Basyiruddin Usman. (2002). Media Pembelajaran, Jakarta: Ciputat Pers.

${ }^{6}$ Adam. Steffi dan Muhammad Taufik Syastra. (2015). Pemanfaatan Media Pembelajaran Berbasis Teknologi Informasi Bagi Siswa Kelas X Sma Ananda Batam. Dalam CBIS Journal, Volume 3 No 2: 79

${ }^{7}$ Purwono. Joni, dkk. (2014). Penggunaan Media Audio-Visual Pada Mata Pelajaran Ilmu Pengetahuan Alam Di Sekolah Menengah Pertama Negeril Pacitan. Dalam Jurnal Teknologi Pendidikan dan Pembelajaran Vol.2, No.2: 127 
yang dapat diraba, dilihat dan didengar dan yang dapat diamati melalui panca indera. Kedua, Tekanan utama terletak pada benda atau hal-hal yang dapat dilihat dan didengar. Ketiga, Media pembelajaran digunakan dalam rangka hubungan (komunikasi) dalam pengajaran antara guru dan siswa. Keempat, Media pembelajaran adalah semacam alat bantu belajar mengajar, baik di dalam maupun di luar kelas. Kelima, Media pembelajaran merupakan suatu "perantara" (medium, media) dan digunakan dalam rangka belajar.Keenam, Media pembelajaran mengandung aspek, sebagai alat dan sebagi teknik yang erat pertaliannya dengan metode belajar. Ketujuh, Karena itu, sebagai tindakan operasional, dalam buku ini digunakan pengertian "media pembelajaran" ${ }^{8}$.Selain ciri-ciri di atas, lalu apa saja yang termasuk dalam media pembelajaran. Dari berbagai jenisjenis media yang dikemukakan di atas, maka dapat disimpulkan bahwa media pembelajaran adalah sarana, metode dan teknik yang digunakan dalam rangka mengidentifikasikan komunikasi dan interaksi antar dosen/guru dan peserta didik dalam proses pembelajaran di sekolah. Fungsi dan Peran Media Pembelajaran Setiap manusia memerlukan belajar untuk mengembangkan pengetahuan, bakat dan minatnya. Dalam pengembangan kemampuan tersebut, seseorang membutuhkan orang lain untuk mendidiknya. Selain itu, peran media juga sangat diperlukan dalam mendidik peserta didik. Hal ini dijelakan oleh (Iwan Falahudin, 2014) bahwa peran pembelajar adalah menyediakan, menunjukkan, membimbing dan memotivasi para pembelajar agar mereka dapat berinteraksi dengan berbagai sumber belajar yang ada. Bukan hanya sumber belajar yang berupa orang, melainkan juga sumbe-sumber belajar yang lain. ${ }^{9}$ Oleh karena itu, dalam meningkatkan kemampunya untuk belajar maka diperlukan sumber belajar. Dengan adanya sumber belajar maka peserta didik dapat mengerti apa yang dipelajarinya. Salah satu sumber belajar yang dikenal selama ini adalah media pembelajaran. Menurut AECT (dalam Ahmad Rohani, 1991), mengklasifikasikan tentang sumber belajar media menjadi enam macam, yaitu: (1). Message (pesan), yaitu informasi/ajaran yang diteruskan oleh komponen lain yang dalam bentuk gagasan, fakta, arti dan data. Termasuk dalam kelompok pesan adalah semua bidang studi/mata kuliah atau bahan pengajaran yang diajarkan kepada peserta didik, dan sebagainya. (2). People (orang), yakni manusia yang bertindak sebagai penyimpan, pengolah dan penyaji pesan. Termasuk kelompok ini misalnya guru/dosen, tutor peserta didik dan sebaginya. (3). Materials (bahan), yaitu perangkat lunak yang mengandung pesan untuk disajikan melalui penggunaan alat perangkat keras atau pun oleh dirinya sendiri. Berbagai program media termasuk media materials seperti transportasi, slide, film, audio, video, modul, majalah, buku dan sebagainya. (4). Device (alat), yakni (suatu perangkat keras) yang digunakan untuk menyampaikan pesan yang tersimpan dalam bahan, misalnya OHP, slide, video, tape recorder, dan sebagainya. (5). Technique (teknik), yaitu prosedur atau acuan yang dipersiapkan untuk penggunaan bahan, peralatan, orang, lingkungan untuk menyampaikan pesan. Misalnya pengajaran terprogram/modul, simulasi, demonstrasi, tanya jawab, CBSA, dan sebagainya. (6). Setting (lingkungan), yaitu situasi atau suasana sekitar di mana pesan disampaikan. Baik lingkungan fisik ruang kelas, gedung sekolah, perpustakaan, laboratorium, taman, lapangan, dan sebagainya. Juga lingkungan non fisik, misalnya suasana belajar itu sendiri, tenang, lelah, ramai dan sebagainya. ${ }^{10}$ Pada dasarnya, media adalah sebagai alat komunikasi yang digunakan dalam proses belajar mengajar. Sebagai alat

\footnotetext{
${ }^{8}$ Hamalik, Oemar. (1994). Media Pendidikan, Bandung: Citra Adtya Bakti

${ }^{9}$ Falah. Iwan, Pemanfaatan Media dalam Pembelajaran. Dalam Jurnal Lingkar Widyaiswara
} Edisi 1 No. 4:104-117

${ }^{10}$ Rohani, Ahmad. (1991). Pengelolaan Pelajaran, Jakarta: Rineka Cipta. 
komunikasi, media pembelajaran menurut (Oemar Hamalik, 1994) memiliki fungsi yang luas di antaranya: (a). Fungsi edukatif media komunikasi, yakni bahwa setiap kegiatan media komunikasi mengandung sifat mendidik karena di dalamnya memberikan pengaruh pendidikan. (b). Fungsi sosial media komunikasi, media komunikasi memberikan informasi aktual dan pengalaman dalam berbagai bidang kehidupan sosial orang. (c). Fungsi ekonomis media komunikasi, media komunikasi dapat digunakan secara intensif pada bidang-bidang pedagang dan industri. (d). Fungsi politis media komunikasi, dalam bidang politik media komunikasi dapat berfungsi terutama politik pembangunan baik material maupun spiritual. (e). Fungsi seni dan budaya media komunikasi, perkembangan ke bidang seni dan budaya dapat tersebar lewat media komunikasi. ${ }^{11}$ Dari sekian fungsi media pembelajaran di atas, (Arif Sadiman,1993),menguraikan beberapa fungsi media pembelajaran, yaitu: (a). Memperjelas penyajian pesan agar tidak terlalu bersifat verbalistik (dalam bentuk kata-kata tertulis atau lisan belaka). (b). Mengatasi keterbatasan ruang, waktu, dan daya indera, seperti misalnya:1) Obyek yang terlalu besar bisa digantikan oleh realita, gambar, film, atau model. 2) Obyek yang kecil dibantu oleh proyektor mikro, film bingkai, film atau gambar. 3) Gerak yang terlalu lamban atau terlalu cepat, dapat dibantu dengan timelapse atau hagh speed photograpy. 4) Kejadian atau peristiwa yang terjadi di masa lalu bisa ditampilkan lagi lewat rekaman film, video, film bingkai, foto atau pun secara verbal. 5) Obyek yang terlalu kompleks (missal mesinmesin) dapat disajikan dengan model, diagram dan lain-lain. 6) Konsep yang terlalu luas (gunung berapi, gempa bumi, iklim dan lain-lain) dapat divisualisasikan dalam bentuk film, film bingkai, gambar dan lain-lain. (c). Penggunaan media pembelajaran secara tepat dan bervariasi dapat diatasi sikap pasif anak didik, dalam hal ini media pembelajaran berguna untuk:1). Menimbulkan kegairahan belajar.2). Memungkinkan belajar interaksi yang lebih langsung antara anak didik dengan lingkungan dan kenyataan.3). Memungkinkan anak didik belajar sendirisendiri menurut kemampuan dan minatnya. (d). Dengan sifatnya yang unik pada tiap siswa, ditambah lagi dengan lingkungan dan pengalaman yang berbeda, sedangkan kurikulum dan materi pendidikan ditentukan sama untuk setiap siswa, maka akan banyak mengalami kesulitan bilamana semuanya itu harus diatasi sendiri, apalagi bila latar belakang lingkungan guru dengan siswa juga berbeda. Masalah ini, dapat diatasi dengan kemampuan dalam: 1) Memberikan rangsangan yang sama. 2) Mempersamakan pengalaman. 3) Menimbulkan persepsi yang sama. Dari uraian di atas, jelaslah bahwa fungsi media pembelajaran sangat berpengaruh terhadap pencapaian tujuan yang telah ditetapkan dalam pendidikan ${ }^{12}$

\section{Metode Penelitian}

Penelitian ini dilaksanakan di Kelas XI SMA Swasta Darussaadah Kec. Pangkalan Susu beralamat di jalan Pertumbukan Km 14,5 Kecamatan Pangkalan Susu. Tindakan pembelajaran ini dilaksanakan pada bulan Februari sampai Maret Tahun 2019 semester Ganjil di kelas XI SMA Swasta Darussaadah Kec. Pangkalan Susu.

Subjek dalam penelitian ini adalah siswa kelas XI SMA Swasta Darussaadah Kec. Pangkalan Susu Tahun Pelajaran 2018-2019 yang berjumlah 40 orang, terdiri dari 20 orang laki-laki dan 20 orang perempuan.

${ }^{11}$ Hamalik, Oemar. (1994). Media Pendidikan, Bandung: Citra Adtya Bakti. Hill. Reginald. (1998) 
Metode Penelitian ini diterapkan adalah metode penelitian tindakan kelas yang dilaksankan melalui dua siklus pembelajaran. Siklus pembelajaran yang digunakan adalah siklus pembelajaran yang dikembangkan oleh Kemmis dan Taggart. Setiap siklus terdiri dari tahapan perencanaan, pelaksanaan, pengamatan dan refleksi.

Tahapan-tahapan pembelajran setiap siklus dapat digambarkan sebagai berikut. Pelaksanaan tiap siklus dalam penelitian ini merupakan siklus kegiatan yang terdiri dari dua siklus dan masing-masing siklus meliputi empat tahap yaitu perencanaan, pelaksanaan, pengamatan dan refleksi.

\section{Tahap Perencanaan}

a. Membuat/ menyusun perencenaan pembelajaran (RPP)

b. Membentuk kelompok secara acak atau heterogen tanpa melihat kepandaian, suku, jenis kelamin dan agama siswa.

c. Menyusun lembar observasi untuk mengetahui aktivitas siswa dan guru selama proses pembelajaran berlangsung.

d. Menyiapkan media pembelajaran.

e. Menyusun tes akhir siklus I untuk mengetahui hasil belajar yang telah dilaksankan.

\section{Tahap Tindakan}

a. Pendahuluan

1. Guru Memberi salam

2. Guru Mengecek Kehadiran Siswa

3. Guru Menanyakan apakah peserta didik sudah membaca materi yang akan dipelajari dan memberi pertanyaan terkait dengan materi yang akan dipelajari.

4. Peserta didik menerima informasi tentang topik dan tujuan pembelajaran dari guru.

5. Peserta didik dibagi menjadi beberapa kelompok tiap kelompok terdiri atas 5 orang.

b. Kegiatan Inti

1. Mengamati

a. Peserta didik mengamati gambar sumber daya alam dalam pemanfaatan sumber daya alam.

b. Berdasarkan hasil pengamatan gambar, peserta didik mendiskusikan di dalam kelompok tentang hal-hal yang ingin diketahui, misalnya bagaimana manfaat udara, kemudian salah satu wakil dari kelompok di minta menuliskan di papan tulis.

c. Peserta didik diajak untuk menyeleksi apakah hal-hal yang ingin diketahui sudah sesuai dengan tujuan pembelajaran, jika belum dengan panduan guru, peserta didik diminta untuk memperbaiki.

d. Jika hal-hal yang ingin diketahui dari hasil pengamatan masih ada yang belum sesuai dengan tujuan pembelajaran, maka guru dapat menambahkan hal-hal yang terkait dengan tujuan pembelajaran.

2. Menanya

a. Peserta didik mendiskusikan dalam kelompok untuk merumuskan pertanyaan berdasarkan hal-hal yang ingin diketahui dari hasil pengamatan gambar, pertanyaan diarahkan ke hal-hal yang terkait dengan tujuan pembelajaran.

b. Satu diantara peserta didik dari wakil kelompok menuliskan rumusan pertanyaan dipapan tulis 
c. Peserta didik mendiskusikan dengan kelompok untuk menjawab pertanyaan sesuai dengan apa yang diketahuinya.

3. Mengumpulkan data (informasi)

Setiap peserta didika dalam satu kelompok mengumpulkan informasi/data untuk mengawal satu dari pertanyaan yang telah dirumuskan dari berbagai sumber seperti : membaca buku siswa, mencari di internet atau membaca buku di perpustakaan.

4. Mengasosiasi/menganalisis data (informasi)

a. setiap peserta didik mengolah dan mengalisis data atau informasi yang telah dikumpulkan dari berbagai sumber untuk menjawab pertanyaan yang telah dirumuskan.

b. Setiap peserta didik menyampaikan kepada anggota kelompoknya terkait dengan jawaban atas pertanyaan yang ditugaskan.

c. Secara bersama-sama peserta dididk merumuskan secara tertulis jawaban dari hasil diskusi kelompok.

5. Mengkomunikasikan

a. dipilih secara acak satu kelompok untuk mempersentasekan hasil diskusi kelompok.

b. Kelompok lain memberi tanggapan atas hasil simpulan kelompok yang persentasi.

c. Peserta didik bersama guru mengambil kesimpulan atas jawaban dari pertanyaan.

c. Kegiatan penutup

1. Guru dan siswa menyimpulkan pembelajaran

2. Peserta didik diberikan kesempatan untuk menanyakan hal-hal yang belum dipahami.

3. Guru memberikan penjelasan atas pertanyaan yang disampaikan oleh peserta didik

4. Peserta didik mengerjakan soal evaluasi siklus 1.

5. Peserta didik menyempurnakan laporan hasil diskusi kelompok tentang jawaban atau pertanyaan yang telah dirumuskan untuk dikumpulkan kepada guru.

6. Peserta didik diberi tugas melakukan pengamatan ramalan cuaca di daerah setempat sebagai bahan pembelajaran pada pertemuan berikutnya.

\section{Tahap Pengamatan}

a. Peneliti berkolaborasi dengan guru pengamat untuk melakukan observasi

b. pengamat mengamati jalannya pembelajaran untuk menilai kemampuan guru dalam mengelola kelas serta aktivitas siswa dalam pembelajaran

c. pengamat mengisi lembar observasi siswa dan guru berdasarkan hasil pengamatan.

\section{Tahap Refleksi}

Pelaksanaan Refleksi dilakukan untuk memahami hal-hal yang berkaitan dengan proses dan hasil yang diperoleh dari tindakan yang telah dilakukan. Melakukan analisis terhadap temuan-temuan yang berupa hambatan, kekurangan dan kelemahan yang dijumpai selama pelaksanaan siklus 1 sebagai masukan untuk perbaikan pembelajaran disiklus selanjutnya.

\section{Hasil Penelitian}

Pada kondisi awal siswa hasilnya menujukkan bahwa 25\% siswa yang dapat mencapai KKM (Kriteria Ketuntasan Minimal) yang diterapkan oleh guru sebesar 7,5 selanjutnya guru, teman sejawat (pengamat) berkolaborasi mencari masalah yang 
menyebabkan $75 \%$ siswa nilainya masih dibawah KKM. Masalah tersebut adalah tingkat penguasaan materi oleh siswa terhadap materi pembelajaran yang masih rendah. Dari 40 siswa yang mendengarkan.

Penjelasan guru hanya 10 siswa yang berani bertanya tentang materi yang disampaikan. Pembelajaran berpusat pada guru adalah pembelajaran yang didominasi oleh guru dengan cara ceramah pada siswa. Maka peneliti dan guru pengamat mengambil kesimpulan untuk mengaktifkan siswa dalam pembelajaran yaitu pembelajaran yang dilaksanakan dengan menggunakan media pembelajaran yang sesuai dengan materi pembelajaran.

Pada awal sebelum diadakan tindakan pembelajaran ketuntasan belajar siswa dari 40 siswa terdapat 10 siswa yang memenuhi KKM dan 30 siswa yang belum memenuhi KKM.

\section{Siklus I}

Pada siklus I, diketahui siswa yang telah mencapai KKM (75) ada 27 siswa $(67,5 \%)$, sedangkan yang belum mencapai KKM 75 sebanyak 13 siswa $(32,5 \%)$.

Pada Tabel 4.2 berikut ini akan dituliskan perolehan nilai siklus I. Hasil yang diperoleh siswa pada siklus I mengalami peningkatan, dari jumlah 40 siswa terdapat 27 siswa mencapai atau melebihi ketuntaasan yang ditetapkan yaitu 75 dan 13 siswa belum mencapai ketuntasan.

Analisis data nilai hasil belajar tersebut dapat diketahui bahwa yang sudah tuntas dengan nilai diatas KKM ada 27 siswa dan yang belum tuntas atau masih dibawah KKM ada 13 siswa dengan nilai tertinggi 85 dan nilai terendah 60. Pada tabel 4.2 dapat dilihat bahwa jumlah siswa yang tuntas belajar sebesar 67,5\%. Sedangkan siswa yang belum tuntas sebesar 32,5\%.

Berdasarkan data aktivitas belajar siswa di kelas diketahui bahwa (1) kesiapa siswa dalam belajar memperoleh skor 99 dengan persentase $61,88 \%$ dan ini tergolong dalam kategori baik (2) menjawab pertanyaan memperoleh skor 94 dengan persentase $58,75 \%$ dan ini tergolong dalam kategorik baik, (3) merumuskan masalah sementara memperoleh skor 75 dengan persentase $48,13 \%$ dan ini tergolong dalam kategori kurang baik, (4) aktif dalam diskusi kelompok memperoleh skor 95 dengan persentase $59,38 \%$ dan ini tergolong dalam kategori baik (5) kedisiplinan siswa dalam pembelajaran memperoleh skor 97 dengan persentase 60,63\% dan ini termasuk kategori baik, (6) melaksanakan diskusi memperoleh skor 98 dengan persentase $61,25 \%$ dan termasuk dalam kategori baik, (7) mengajukan pertanyaan memperoleh skor 97 dnegna persentase 60,63\% dan ini termasuk kategori baik, dan (8) menyimpulkan hasil diskusi memperoleh skor 109 dengan persentase $68,13 \%$ dan ini termasuk dalam kategori baik.

Secara klasikal, aktivitas belajar siswa pada siklus pertama ini memperoleh skor 767 dengan persentase 59,92\% dan termasuk dalam kategori baik. Aktivitas siswa dikatakan berhasil apabila secara klasikal persentase dilakukannya aktivitas dalam proses pembelajaran mencapai minimal $75 \%$. Sedangkan aktivitas belajar siswa pada siklus pertama ini hanya memperoleh $59,92 \%$.

\section{Siklus II}

Berdasarkan pelaksanaan pembelajaran pada siklus II diketahui bahwa siswa yang telah mencapai KKM 75 berjumlah 33 siswa (82,5\%) sedangkan yang belum mencapai KKM 75 sebanyak 7 siswa $(17,5 \%)$.

Berdasarkan hasil belajar siswa pada pelajaran PKN kelas XI SMA Swasta Darussaadah Kec. Pangkalan Susu dapat diketahui bahwa yang sudah tuntas dengan nilai diatas KKM ada 33 siswa dan yang belum tuntas atau masih dibawah KKM ada 
7 siswa, dengan nilai tertinggi 90 dan nilai terendah 66. Pada Tabel 4.3. dapat dilihat bahwa persentase jumlah siswa yang tuntas belajar sebesar $82,5 \%$ sedangkan siswa yang belum tuntas belajar sebesar 17,5\%. Rata-rata klasikal hasil belajar siswa 79,63, sedangkan kriteria ketuntasan minimal yang ditetapkan 75 , ini berarti secara klasikal hasil belajar dikatakan sudah tuntas.

Pelaksanaan pembelajaran pada siklus kedua ini mengacu pada catatan-catatan kekurangan pada siklus pertama. Bedasarkan hasil pengamatan terhadap aktivitas belajar siswa di kelas pada siklus kedua ini diperoleh data yaitu (1) kesiapan belajar siswa dalam belajar memperoleh skor 141 dengan persentase 88,13\% dan ini tergolong dalam kategori sangat baik, (2) menjawab pertanyaan memperoleh skor 123 dengan persetanse $76,89 \%$ dan ini tergolong dalam kategori sangat baik (3) merumuskan masalah sementara memperoleh skor 115 dengan persentase $71,88 \%$ dan ini tergolong dalam kategori baik, (4) aktif dalam diskusi kelompok memperoleh skor 135 dengan persentase $84,38 \%$ dan ini tergolong dalam kategori sangat baik, (5) kedisiplinan siswa dalam pembelajaran memperoleh skor 142 dengan persentase $88,75 \%$ dan termasuk dalam kategori sangat baik, (6) melaksanakan diskusi memperoleh skor 136 dengan persentase $85,0 \%$ dan termasuk dalam kategori sangat baik, (7) mengajukan pertanyaan memperoleh skor 140 dengan persentase 87,50\% dan ini termasuk dalam kategori sangat baik, dan (8) menyimpulkan hasil diskusi memperoleh skor 157 dengan persentase 98,13\% dan ini termasuk dalam kategori sangat baik.

Secara klasikal aktivitas belajar siswa pada siklus kedua ini memperoleh skor 1089 dengan persentase $85,08 \%$ dan termasuk kategori sangat baik, jika dibandingkan dengan standar keberhasilan untuk aktivitas belajar siswa ini, maka aktivitas belajar siswa dalam proses pembelajar dikatakan berhasil apabila mencapai minimal $75 \%$ sedangkan aktivitas belajar siswa pada siklus kedua ini memperoleh persentase sebesar $85,08 \%$ maka aktivitas belajar siswa dikatakan sudah berhasil atau mengalami peningkatan yang sangat baik.

Berdasarkan hasil analisa data, kegiatan pembelajaran di kelas XI SMA Swasta Darussaadah Kec. Pangkalan Susu, kabupaten Langkat terlihat bahwa ada peningkatan nilai rata-rata hasil belajar siswa setelah diadakan tindakan pembelajaran dengan melengkapi media pembelajaran. Nilai rata-rata sebelum dilakukan tindakan pembelajaran 65,75 dan setelah dilakukan tindakan pada siklus 1 nilai rata-rata menjadi 73,23 ini berarti pembelajaran telah berhasil meningkatkan rata-rata hasil belajar sebesar 7,48 dari pra siklus I. Tetapi nilai rata-rata ini masih dibawah nilai kriteria ketuntasan minimal yang ditetapkan $(\mathrm{KKM}=75)$ dan indikator keberhasilan (ketuntasan) 80\% dimana jumlah siswa yang tuntas sebanyak 27 orang atau 67,5\%. Jadi tindakan pembelajaran harus dilanjutkan ke siklus ke dua dengan beberapa perbaikan pembelajaran bedasarkan hasil refleksi.

Pada siklus kedua diperoleh nilai rata-rata hasil belajar siswa 79,63 dengan jumlah siswa yang tuntas 33 orang atau 82,5\%. Ini berarti nilai rata-rata yang diperoleh sudah mencapai KKM yang ditetapkan sehingga indikator ketuntasan belajar siswa tercapai. Demikian juga dengan jumlah siswa yang tuntas sudah mencapai indikator keberhasilan, dimana standar yang ditetapkan $80 \%$ sedangkan perolehan mencapai $82,5 \%$.

Mengenai aktivitas belajar siswa, pada siklus pertama memperoleh skor kalsikal 767 dengan persentase skor prolehan terhadap skor total sebesar 59,92\% dan ini termasuk kategori baik pada siklus ke dua aktivitas siswa secara klasikal memperoleh skor 1089 dengan persentase skor prolehan terhadap skor total sebesar $85,05 \%$ dan ini termasuk dalam kategori sangat baik. 


\section{Kesimpulan}

Berdasarkan hasil analisis data dapat disimpulkan: 1) Melalui penerapan pembelajaran dengan menggunakan media pembelajaran yang lengkap pada pembelajaran PKN di kleas XI SMA Swasta Darussaadah Kec. Pangkalan Susu tahun pelajaran 2018/2019, akativitas belajar siswa mengalami peningkatan dari siklus I ke siklus II. Aktivitas belajar siswa, pada siklus pertama memperoleh skor 767 dengan persentase skor perolehan terhadap skor total sebesar 59,92\% dan ini termasuk kategori baik. Pada siklus ke dua aktivitas siswa secara klasikal memperoleh skor 1089 dengan persentase skor perolehan terhadap skor total sebesar 85,08\% dan ini termasik dalam kategori sangat baik. 2) Hasil belajar siswa setelah diterapkan dengan menggunakan media pembelajaran yang lengkap pada pembelajaran PKN dikelas XI SMA Swasta Darussaadah Kec. Pangkalan Susu tahun pelajaran 2018/2019 mengalami peningkatan. Pada siklus I perolehan nilai rata-rata klasikal 73,23. Nilai rata-rata ini masih dibawah kriteria ketuntasan yang ditetapkan $(\mathrm{KKM}=75)$ dan indikator keberhasilan (ketuntasan) $80 \%$ dinama jumlah siswa yang tuntas sebanyak 27 orang atau 67,50\%. Jadi tindakan pembelajaran harus dilanjutkan ke Siklus Kedua dengan beberapa perbaikan. Pada siklus kedua diperoleh nilai rata-rata hasil belajar siswa 79,63 dengan jumlah siswa yang tuntas 33orang siswa atau 82,5\% ini berarti nilai rata-rata yang diperoleh sudah mencapai KKM yang ditetapkan

\section{Daftar Pustaka}

Ahmadi dkk, Drs. H. Abu. (2004). Psikologi Belajar. Jakarta : PT. Rineka Cipta. Vol. 2.

Adam. Steffi dan Muhammad Taufik Syastra. (2015). Pemanfaatan Media Pembelajaran Berbasis Teknologi Informasi Bagi Siswa Kelas X Sma Ananda Batam. Dalam CBIS Journal, Volume 3 No 2: 79

Asnawir dan M. Basyiruddin Usman. (2002). Media Pembelajaran, Jakarta: Ciputat Pers.

Azhar, Arsyad. 2009. Media Pembelajaran. Jakarta.; Raja Grafindo Persada, Rineka Cipta.

Hamalik, Oemar. (1994). Media Pendidikan, Bandung: Citra Adtya Bakti

Hamalik, Oemar. (1994). Media Pendidikan, Bandung: Citra Adtya Bakti. Hill. Reginald. (1998).

Falah. Iwan, Pemanfaatan Media dalam Pembelajaran. Dalam Jurnal Lingkar Widyaiswara Edisi 1 No. 4:104-117

Mahnun.Nunu.(2012). Media Pembelajaran (Kajian terhadap Langkah-langkah Pemilihan Media dan Implementasinya dalam Pembelajaran). Dalam Jurnal Pemikiran Islam; Vol. 37, No. 1: 27

Purwono. Joni, dkk. (2014). Penggunaan Media Audio-Visual Pada Mata Pelajaran Ilmu Pengetahuan Alam Di Sekolah Menengah Pertama Negeril Pacitan. Dalam Jurnal Teknologi Pendidikan dan Pembelajaran Vol.2, No.2: 127

Rohani, Ahmad. (1991). Pengelolaan Pelajaran, Jakarta: Rineka Cipta.

Sardiman, Arif. 2008. Media Pendidikan. Jakarta: Kencana Prenada Media Group. 